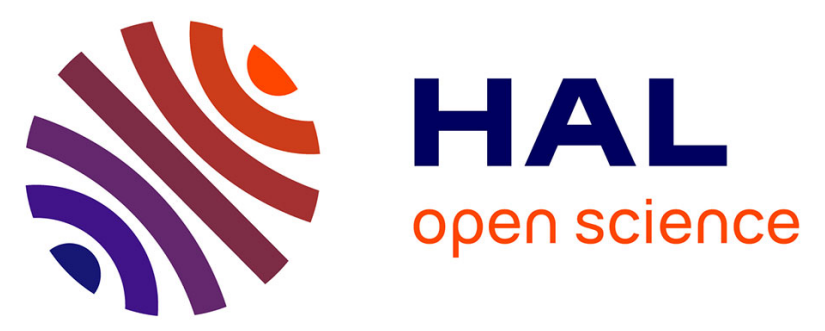

\title{
Remote Deprotometalation-Iodolysis of N,N-Diisopropyl-2-trimethylsilylferrocenecarboxamide: A New Route Toward 1,1'-Disubstituted Ferrocenes
}

\author{
Lingaswamy Kadari, Thierry Roisnel, William Erb, Palakodety Radha \\ Krishna, Florence Mongin
}

\section{To cite this version:}

Lingaswamy Kadari, Thierry Roisnel, William Erb, Palakodety Radha Krishna, Florence Mongin. Remote Deprotometalation-Iodolysis of N,N-Diisopropyl-2-trimethylsilylferrocenecarboxamide: A New Route Toward 1,1'-Disubstituted Ferrocenes. Synthesis: Journal of Synthetic Organic Chemistry, 2020, 52 (21), pp.3153-3161. 10.1055/s-0040-1707175 . hal-02948487

HAL Id: hal-02948487

https://hal-univ-rennes1.archives-ouvertes.fr/hal-02948487

Submitted on 3 Dec 2020

HAL is a multi-disciplinary open access archive for the deposit and dissemination of scientific research documents, whether they are published or not. The documents may come from teaching and research institutions in France or abroad, or from public or private research centers.
L'archive ouverte pluridisciplinaire HAL, est destinée au dépôt et à la diffusion de documents scientifiques de niveau recherche, publiés ou non, émanant des établissements d'enseignement et de recherche français ou étrangers, des laboratoires publics ou privés. 


\section{Remote deprotometalation-iodolysis of $\mathrm{N}, \mathrm{N}$-diisopropyl-2-trimethylsilyl- ferrocenecarboxamide: a new route toward 1,1'-disubstituted ferrocenes}

\author{
Lingaswamy Kadaria,b \\ Thierry Roisnela \\ William Erb*a \\ Palakodety Radha Krishna*b \\ Florence Mongin ${ }^{a}$ \\ a Univ Rennes, CNRS, ISCR (Institut des Sciences Chimiques de \\ Rennes)-UMR 6226, F-35000 Rennes, France. \\ b Organic Synthesis and Process Chemistry Division, CSIR- \\ Indian Institute of Chemical Technology, Hyderabad, 500007, \\ India. \\ william.erb@univ-rennes1.fr \\ prkgenius@iict.res.in
}

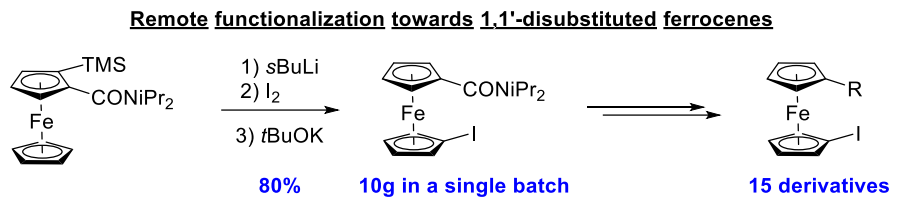

Abstract The $1,1^{\prime}$-disubstitution is currently the most frequent substitution pattern encountered in the ferrocene series. Here we report an original access based on the remote deprotometalation of $\mathrm{N}, \mathrm{N}$-diisopropyl-2 trimethylsilylferrocenecarboxamide. The key intermediate, $1^{\prime}$-iodo- $N, N$ diisopropylferrocenecarboxamide, was prepared in multiple grams and was further functionalized toward fifteen $1^{\prime}$-substituted iodoferrocenes.

Key words Ferrocene; 1,1'-Disubstitution; Carboxamide; Remote functionalization; Functional group manipulation

The discovery of ferrocene in 1952 has profoundly changed the organometallic chemistry landscape and this sandwich compound remains one of the most important organometallic scaffolds. ${ }^{1}$ Among the various substitution patterns explored in ferrocene chemistry, the most popular is the 1,1'-disubstitution, with applications in catalysis, ${ }^{2}$ material science $^{3}$ and bioinorganic chemistry. ${ }^{3 a}, 4$

1,1'-Disubstituted ferrocenes with the same substituents can easily be obtained by two complementary approaches: (1) the ferrocene core assembly from the corresponding monosubstituted cyclopentadienes ${ }^{5}$ and (2) the double deprotometalation-electrophilic trapping sequence from ferrocene. ${ }^{6}$ However, while $1^{\prime}$-substituted iodoferrocenes represent an important family of precursors to unsymmetrical compounds, ${ }^{7}$ they cannot be directly prepared by one of the above mentioned approaches. Therefore, the most popular synthetic routes currently rely on the halogen/Li or Sn/Li monoexchange of such 1,1'-disubstituted ferrocenes. Buttler initially reported the mono I/Li exchange from 1,1'-diiodoferrocene using $n \mathrm{BuLi}$, followed by an electrophilic trapping step (Scheme 1, approach a, $\left.\mathrm{R}=\mathrm{CO}_{2} \mathrm{H}, \mathrm{SnBu}_{3}\right) .{ }^{8}$ However, low yields were obtained (28-32\%), linked with the highly sensitive nature of the reaction as expressed in a footnote. Similar low yields were recorded by Christmann, Sarkar and Heretsch using tosyl azide as the electrophile ${ }^{9}$ while Lentz and later Nijhuis, both using tributyltin chloride, managed to isolate 1-iodo-1'- tributylstannylferrocene in good yields (77 and 84\%, respectively). ${ }^{10}$ The concentration was proposed as being an important reaction parameter in such reactions, ${ }^{11}$ and the development of a flow-based approach partially solved this issue. ${ }^{9}$ From 1,1'-bis(tributylstannyl)ferrocene, Wright reported a controlled $\mathrm{Sn} / \mathrm{Li}$ mono-exchange by using $n \mathrm{BuLi}$ before interception with an electrophile. ${ }^{12}$ However, iodine cannot be introduced this way due to a competitive Sn/I exchange leading to mixtures of products. Therefore, another substituent needs to be introduced first, before performing the final Sn/I exchange using iodine. Such approach was illustrated with success during the synthesis of 1'-iodoferrocenecarboxaldehyde (Scheme 1, approach b, R = CHO).13 Finally, Dong developed a mono Li/Br exchange-electrophilic trapping sequence from 1,1'dibromoferrocene; ${ }^{14}$ this was used by Ilyashenko as the key step in the synthesis of 1-bromo-1'-iodoferrocene (78\% yield; Scheme 1 , approach c, $\mathrm{R}=\mathrm{Br}) \cdot{ }^{11}$

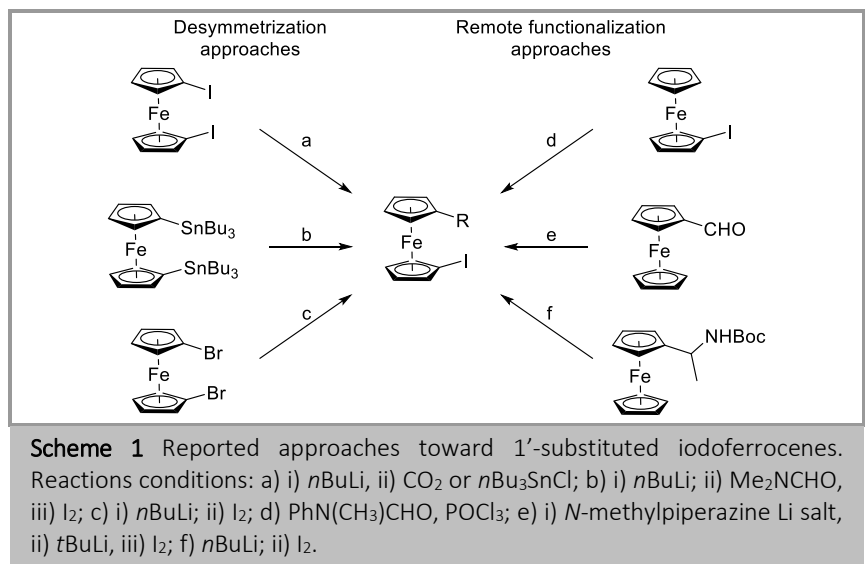

The other strategies toward 1'-substituted iodoferrocene start from monosubstituted ferrocenes and rely on functionalizations at the unsubstituted cyclopentadienyl $(\mathrm{Cp})$ ring, remote from the 
substituent. The regioselective aromatic electrophilic substitution of iodoferrocene using acetyl chloride in the presence of iron trichloride was first attempted by Richards. ${ }^{15}$ However, the expected 1,1'-disubstituted product was not obtained due to competitive deiodination observed under the reaction conditions. However, by using $N$-methylformanilide in the presence of phosphorus oxychloride, Yuan managed to isolate the corresponding 1'-iodoferrocenecarboxaldehyde in a moderate $61 \%$ yield (Scheme 1, approach $\mathrm{d}, \mathrm{R}=\mathrm{CHO}$ ). ${ }^{16}$

The use of directing groups able to reroute the classical orthodeprotometalation to the unsubstituted $\mathrm{Cp}$ ring represents the second approach in the remote functionalization strategy. Balavoine and Manoury reported the reaction of the lithium salt of $N$-methylpiperazine with ferrocenecarboxaldehyde, followed by a deprotolithiation-electrophilic trapping sequence toward 1'iodoferrocenecarboxaldehyde in a moderate $50 \%$ yield (Scheme 1, approach e, $\mathrm{R}=\mathrm{CHO}$ ). ${ }^{17}$ The $\mathrm{N}$-methylpiperazine acts as a protecting group for the aldehyde (temporary formation of the hemiaminal salt) and as the directing group with methylated nitrogen atom. More recently, Chong revealed a similar behaviour for $N$-Boc protected $\alpha$-methylated aminomethylferrocene in deprotolithiation and managed to obtain the corresponding iodinated derivative in a $71 \%$ yield (Scheme 1 , approach $\mathrm{f}, \mathrm{R}=\mathrm{CH}(\mathrm{Me}) \mathrm{NHBoc}){ }^{18}$

A few other catalytic desymmetrizations of 1,1'-diiodoferrocene have been reported, based on Stille, ${ }^{10 a}, 19$ Sonogashira, ${ }^{20}$ SuzukiMiyaura $^{21}$ and Ulmann ${ }^{22}$ cross-couplings and by aminocarbonylation. ${ }^{23}$ However, the selectivity is often an issue in such transformations, leading to mixtures of products.

In the frame of ongoing studies dedicated to the synthesis of original ferrocene derivatives, ${ }^{24}$ we required an access to different 1 '-substituted iodoferrocene derivatives. We initially focused our work on the mono-exchange of 1,1'-diiodoferrocene by using $n \mathrm{BuLi}$, as this approach has the potential to easily deliver many derivatives by varying the electrophile. ${ }^{8}$ However, regardless of the reaction conditions, only traces of the desired products were invariably obtained while 1,1'-bis-functionalized derivatives and mixtures of 1,1'-diiodoferrocene, iodoferrocene and ferrocene were mainly obtained. We briefly evaluated the Manoury approach, ${ }^{17}$ but failed to obtain significant amounts of the title products by using iodine as the electrophile. Moderate success was encountered in our attempts to achieve a mono Sn/Li exchange from 1,1'-bis(tributylstannyl)ferrocene ${ }^{12}$ by using $n \mathrm{BuLi}$ and either methyl chloroformate or dimethylformamide as the electrophile (22 or $25 \%$ yield, respectively). However, as we recognized that the synthesis of the targeted compounds would require the manipulation of large quantities of toxic stannylated products, the need for another original approach emerged.

In his seminal paper on the enantioselective deprotometalation of $\mathrm{N}, \mathrm{N}$-diisopropylferrocenecarboxamide, ${ }^{25}$ Snieckus reported that the introduction of a trimethylsilyl group at position 2 was able to reroute a further deprotometalation to the unsubstituted $\mathrm{Cp}$ ring. While a similar behavior was also noticed by Richards on ferrocene oxazolines, ${ }^{26}$ this remote functionalization has never been considered as a valuable synthetic tool. Therefore, our plan was to use a silyl group to temporarily protect the position next to the carboxamide and favor the remote deprotometalation to introduce iodine onto the unsubstituted ring. Final deprotection of the silyl group would afford the targeted 1,1'-disubstituted ferrocenes.

We first deprotolithiated $N, N$-diisopropylferrocenecarboxamide $^{27}$ (1) by using the $n \mathrm{BuLi} \cdot \mathrm{TMEDA}$ (TMEDA: $N, N, N^{\prime}, N^{\prime}$-tetramethylethylenediamine) chelate before intercepting the lithiated intermediate with trimethylsilyl chloride toward the ferrocene rac-2, isolated in a 92\% yield (Scheme 2). To reach the iodinated derivative $\mathbf{r a c}$-3, we initially applied the Snieckus reaction conditions by using $s$ BuLi (1.2 equiv) in THF at cryogenic temperature $\left(-80\right.$ to $\left.-78{ }^{\circ} \mathrm{C}\right)$ before addition of iodine as the electrophile. ${ }^{25}$ However, the title product was isolated in a disappointing 50\% yield together with recovered starting material. While recourse to the more reactive $s$ BuLi-TMEDA chelate improved the conversion to 95\%, formation of inseparable by-products was noticed. However, the use of 2 equivalents of $s \mathrm{BuLi}$ at cryogenic temperature (-80 to $78{ }^{\circ} \mathrm{C}$ ) led to a complete conversion and the ferrocene rac-3 was isolated in a $95 \%$ yield on a $1 \mathrm{mmol}$ scale. Pleasingly, the yield remained constant upon scaling up (97\% yield on a $26 \mathrm{mmol}$ scale). Although the trimethylsilyl group is usually removed upon treatment with fluorides, ${ }^{28}$ we found that rac-3 was reluctant to desilylation under smooth reaction conditions ( 2 equivalents of tetrabutylammonium fluoride at room temperature) and that decomposition occurred upon heating. However, the use of a stoichiometric amount of potassium tert-butoxide in dimethylsulfoxide afforded 4 in a promising $70 \%$ yield after only 5 min.29 Evaluation of other reaction conditions revealed a complete conversion with increased amount of potassium tertbutoxide, reaction time and concentration, delivering 4 in an $80 \%$ yield on a $1 \mathrm{mmol}$ scale. Furthermore, it was possible to scale-up the reaction up to $25 \mathrm{mmol}$ with a slightly better yield (88\%, 10 $\mathrm{g}$ of product 4 made in a single batch).

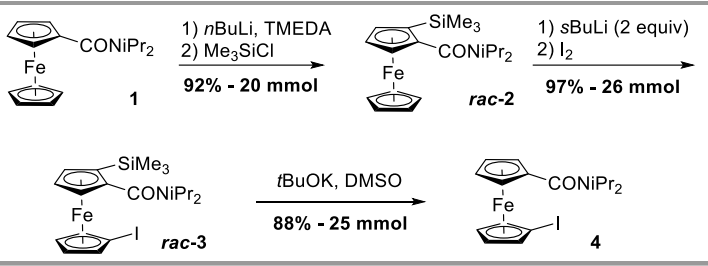

Scheme 2 Remote functionalization strategy toward the 1,1'-disubstituted ferrocene 4. DMSO: dimethylsulfoxide.

Clues about the origin of this remote functionalization can be found in the solid-state structure of compound rac-2. Indeed, to release the steric pressure generated between the diisopropyl and trimethysilyl moieties, the $\mathrm{C}=\mathrm{O}$ bond of the carboxamide needs to be almost perpendicular to the $\mathrm{Cp}$ ring (Scheme 3, right and S.I.). As shown by a variable temperature ${ }^{1} \mathrm{H}$ NMR study (see S.I.), rotation of the $\mathrm{C}=\mathrm{O}$ to reach the conformation favorable to the ortho-deprotometalation $(\mathrm{C}=\mathrm{O}$ parallel with the $\mathrm{Cp}$ ring, Scheme 3, left), is too energetic. Therefore, the only reaction observed is the remote deprotometalation, probably favored by the $\mathrm{C}=\mathrm{O}$ bound pointing toward the unsubstituted $\mathrm{Cp}$ ring to guide the approach of the lithiated base (Scheme 3, right). 


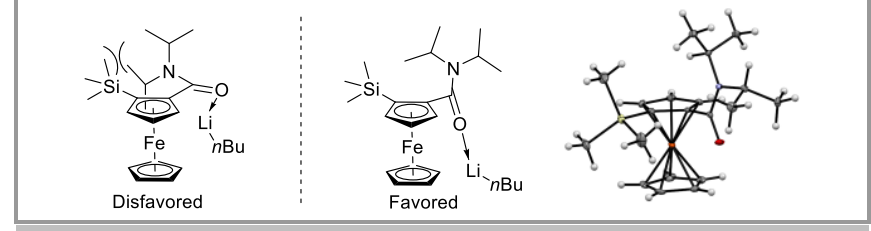

Scheme 3 Rationalization of the origin of the remote deprotometalation.

With a reliable protocol toward $\mathbf{4}$ in hands, we next focused our attention onto the carboxamide transformation. While the borane-mediated reduction of similar substrates is well known, ${ }^{25,30}$ transformation of the resulting diisopropylamine moiety did not receive much attention ${ }^{31}$ until we recently documented the substitution of this bulky amine for an acetate. ${ }^{32}$ Consequently, the carboxamide $\mathbf{4}$ was reduced by an excess of borane (generated in situ from sodium borohydride and iodine) in refluxing tetrahydrofuran to deliver $\mathbf{5}$ in a 95\% yield (Scheme 4). The substitution step then occurred smoothly in neat acetic anhydride at $160{ }^{\circ} \mathrm{C}$ for $1 \mathrm{~h}$ and 6 was isolated in a $88 \%$ yield on a $20 \mathrm{mmol}$ scale ( $6.7 \mathrm{~g}$ of compound in a single batch). During the reduction of $\mathbf{4}$ to $\mathbf{5}$, traces of a by-product, tentatively assigned to be 1-iodo-1'-methylferrocene (7), were noticed. To validate its structure, we engaged the acetate in another borane reduction and indeed isolated $\mathbf{7}$ in a $92 \%$ yield.

Scheme 4 Functional group manipulation toward the methylated derivative 7 .
THF: tetrahydrofuran.

Saponification of the acetate 6 with sodium hydroxide in a tetrahydrofuran-water mixture at $80^{\circ} \mathrm{C}$ led to the isolation of the alcohol 8 in a $90 \%$ yield (Scheme 5). It should be noted that the use of methanol-water mixtures in such reaction should be avoided as variable amounts of the methyl ether $\mathbf{9}$ can be formed as a side-product. However, it is possible to obtain $\mathbf{9}$ in an almost quantitative yield by the deprotonation of the alcohol using sodium hydride followed by the interception of the alkoxide with methyl iodide. The known aldehyde $\mathbf{1 0}$ then was prepared by a ruthenium-mediated oxidation in the presence of $\mathrm{N}$ methylmorpholine oxide initially described by Sharpless. ${ }^{33}$ Addition of phenylmagnesium bromide to the aldehyde afforded the alcohol 11 in a 97\% yield, which was finally converted into the known ketone $\mathbf{1 2}$ in a $96 \%$ yield by following the same ruthenium-mediated oxidation protocol.

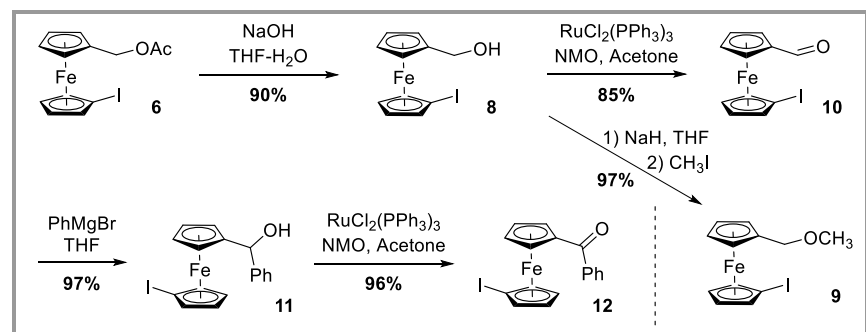

Scheme 5 Functional group manipulation toward the ketone 12. NMO: Nmethylmorpholine oxide.
While condensation of the aldehyde $\mathbf{1 0}$ with hydroxylamine followed by dehydration led to 1 '-iodoferrocenecarbonitrile (13) in $91 \%$ yield (Scheme 6), ${ }^{34}$ it is known that such substrates are difficult to oxidize under classical conditions. ${ }^{35}$ However, reaction of $\mathbf{1 0}$ with iodine in the presence of potassium hydroxide ${ }^{36}$ in methanol led to the ester 14 in a very good $97 \%$ yield. The acid 15 was easily made by saponification in $96 \%$ yield and it was further reacted with diphenylphosphoryl azide by following our recently developed protocol ${ }^{37}$ toward the acyl azide 16, isolated in an $85 \%$ yield. Curtius rearrangement at 110 ${ }^{\circ} \mathrm{C}$ in the presence of tert-butanol to intercept the intermediate isocyanate allowed the isolation of the Boc-protected aminoferrocene $\mathbf{1 7}$ (85\% yield). Removal of the protecting group was easily done by using an ethereal solution of $\mathrm{HCl}$ at room temperature toward 18, isolated in a $74 \%$ yield as its $\mathrm{HCl}$ salt. Although salts of aminoferrocene derivatives are known to be more stable when compared to the free base, storage of $\mathbf{1 8}$ in a closed vessel without specific protection led to decomposition. A double reductive amination ${ }^{38}$ with paraformaldehyde in the presence of an excess of sodium cyanoborohydride was finally performed toward the sensitive dimethylaminoferrocene 19, isolated in a $40 \%$ yield.

Scheme 6 Functional group manipulation toward the dimethylaminoferrocene

In conclusion, we have reported a new route toward 1'substituted iodoferrocenes based on a remote deprotometalation observed more than 20 years ago and never exploited. By following this methodology, grams of our key substrate, 1'-iodo$\mathrm{N}, \mathrm{N}$-diisopropylferrocenecarboxamide, were prepared and further functionalized towards fifteen 1,1'-disubstituted ferrocenes, most of them being fully described for the first time.

General Considerations. Unless otherwise stated, all the reactions were performed under an argon atmosphere with anhydrous solvents using Schlenk technics. THF and $\mathrm{Et}_{2} \mathrm{O}$ were distilled over sodiumbenzophenone, DMSO and toluene were distilled over $\mathrm{CaH}_{2}$ and acetone and methanol were dried by prolonged contact over activated $3 \AA$ molecular sieve. ${ }^{39}$ Unless otherwise stated, all reagents were used without prior purification. All organolithiated reagents were titrated before use. ${ }^{40}$ tBuOK (99.99\% quality) was purchased from Sigma-Aldrich and used without further purification. Column chromatography separations were achieved on silica gel (40-63 $\mu \mathrm{m})$. All Thin Layer Chromatographies (TLC) were performed on aluminum backed plates pre-coated with silica gel (Merck, Silica Gel 60 F254). They were visualized by exposure to UV light. Melting points were measured on a Kofler bench. IR spectra were taken on a Perkin-Elmer Spectrum 100 spectrometer. ${ }^{1} \mathrm{H}$ and ${ }^{13} \mathrm{C}$ Nuclear Magnetic Resonance (NMR) spectra were recorded either (i) on a Bruker Avance III spectrometer at $300 \mathrm{MHz}$ and $75.4 \mathrm{MHz}$, respectively, or (ii) on a Bruker Avance III at $400 \mathrm{MHz}$ and $100 \mathrm{MHz}$, respectively or (iii) on a Bruker Avance III HD at $500 \mathrm{MHz}$ and $126 \mathrm{MHz}$, respectively. ${ }^{1} \mathrm{H}$ chemical shifts $(\delta)$ are given in ppm relative to the solvent residual peak and ${ }^{13} \mathrm{C}$ chemical shifts are relative to the central peak of the solvent signal. $\mathrm{Cp}$ refers to the unsubstituted cyclopentadienyl ring of ferrocene. 


\section{Procedures}

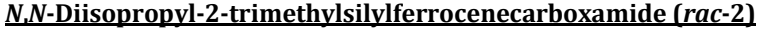

[CAS Reg. No. 173910-99-1]

TMEDA (4.50 mL, $3.49 \mathrm{~g}, 30.0 \mathrm{mmol}, 1.50$ equiv, freshly distilled over $\mathrm{CaCl}_{2}$ and stored over $\mathrm{KOH}$ pellets) and anhydrous $\mathrm{Et}_{2} \mathrm{O}(90.0 \mathrm{~mL})$ were introduced into a flame-dried round-bottom flask under argon. The reaction mixture was cooled between -80 and $-78{ }^{\circ} \mathrm{C}$ (external temperature) in an acetone/liquid nitrogen bath. $n \operatorname{BuLi}(1.4 \mathrm{M}, 21.4 \mathrm{~mL}$ $30.0 \mathrm{mmol}, 1.50$ equiv) was then introduced dropwise by syringe. After addition, the reaction mixture was stirred at the same temperature for 15 min. Compound $\mathbf{1}$ (6.26 g, $20.0 \mathrm{mmol}, 1.00$ equiv) was introduced into a separate flame-dried round-bottom flask which was subjected to three cycles of vacuum/argon. Anhydrous $\mathrm{Et}_{2} \mathrm{O}(90.0 \mathrm{~mL})$ was added and the solution was stirred until dissolution of all solids. The solution of $\mathbf{1}$ was transferred into the $n \mathrm{BuLi} \cdot \mathrm{TMEDA}$ chelate solution dropwise by cannula keeping the temperature between -80 and $-78{ }^{\circ} \mathrm{C}$. The flask was washed with $10.0 \mathrm{~mL}$ of anhydrous $\mathrm{Et}_{2} \mathrm{O}$, also transferred by cannula. After addition, the reaction mixture was stirred at the same temperature for 1 h. $\mathrm{Me}_{3} \mathrm{SiCl}$ ( $5.10 \mathrm{~mL}, 4.34 \mathrm{~g}, 40.0 \mathrm{mmol}, 2.00$ equiv) was added dropwise by syringe keeping the temperature between -80 and $-78^{\circ} \mathrm{C}$. The reaction mixture was then allowed to warm to $-15{ }^{\circ} \mathrm{C}$, keeping the flask into the bath. At $-15{ }^{\circ} \mathrm{C}$, the cooling bath was removed and the reaction mixture was warmed to rt. Water $(100 \mathrm{~mL})$ was added and the layers were separated. The aqueous layer was extracted with EtOAc $(2 \times 75 \mathrm{~mL})$. The combined organic layers were washed with brine, dried over $\mathrm{MgSO}_{4}$ filtrated over cotton wool and concentrated under vacuum using a rotary evaporator to give the crude product. This was purified by column chromatography, using PET-EtOAc $(80: 20)$ to give the title product rac-2 as an orange solid (7.12 g, 92\%). Analytical data analogous to those reported previously. ${ }^{25}$ CCDC 2004798.

Mp $108-110^{\circ} \mathrm{C}$

$v_{\max }\left(\right.$ film) $/ \mathrm{cm}^{-1} 2966,1628,1441,1368,1328,1278,1243,1148,1035$ $833,807,753$.

${ }^{1} \mathrm{H}$ NMR $\left(300 \mathrm{MHz}, \mathrm{CDCl}_{3}\right): \delta(\mathrm{ppm}) 4.34(\mathrm{dd}, J=1.2,2.3 \mathrm{~Hz}, 1 \mathrm{H}, \mathrm{H} 5), 4.29$ (t, $J=2.3 \mathrm{~Hz}, 1 \mathrm{H}, \mathrm{H} 4), 4.27$ (s, 5H, Cp), 4.13 (dd, $J=1.2,2.3 \mathrm{~Hz}, 1 \mathrm{H}, \mathrm{H} 3$ ), 4.11 (br s, 1H, CH), 3.39 (br s, 1H, CH), 1.45 (br s, 6H, 2 x CH 3 ), 1.11 (br s, 6H, 2 $\left.\mathrm{x} \mathrm{CH}_{3}\right), 0.27$ (s, 9H, $\left.\mathrm{Si}\left(\mathrm{CH}_{3}\right)_{3}\right)$.

${ }^{13} \mathrm{C}$ NMR (126 MHz, CDCl 3 ): $\delta(\mathrm{ppm}) 168.9(\mathrm{C}=0), 92.3$ (C1), $73.7(\mathrm{C} 2), 73.5$ (C3), 69.9 (Cp + C5), 69.4 (C4), $50.1(\mathrm{CH}), 45.9(\mathrm{CH}), 21.1\left(2 \times \mathrm{CH}_{3}\right), 20.9$ $\left(2 \times \mathrm{CH}_{3}\right), 0.7\left(\mathrm{Si}\left(\mathrm{CH}_{3}\right)_{3}\right)$.

\section{1'-Iodo- $N, N$-diisopropyl-2-trimethylsilylferrocenecarboxamide $\underline{\text { (rac-3) }}$}

$s$ BuLi (1.2 M, $43.3 \mathrm{~mL}, 52.0 \mathrm{mmol}, 2.00$ equiv) was added dropwise to a solution of rac-2 (10.0 g, $26.0 \mathrm{mmol}, 1.00$ equiv) in anhydrous $\mathrm{Et}_{2} \mathrm{O}$ (300 $\mathrm{mL}$ ) between -80 and $-78{ }^{\circ} \mathrm{C}$. The reaction mixture was stirred at the same temperature for $1 \mathrm{~h}$ after addition. Iodine ( $19.8 \mathrm{~g}, 78.0 \mathrm{mmol}, 3.00$ equiv) was introduced in a separate flame-dried round-bottomed flask under argon and was dissolved in anhydrous $\mathrm{Et}_{2} \mathrm{O}(300 \mathrm{~mL})$. The iodine solution was transferred by cannula into the reaction mixture. The flask was washed with $10.0 \mathrm{~mL}$ of anhydrous $\mathrm{Et}_{2} \mathrm{O}$, also transferred by cannula. After addition, the reaction was stirred at the same temperature for 30 min before being warmed to rt. A saturated aqueous solution of $\mathrm{Na}_{2} \mathrm{~S}_{2} \mathrm{O}_{3}$ $(100 \mathrm{~mL})$ was added to the reaction mixture and the layers were separated. The aqueous layer was extracted with EtOAc $(2 \times 100 \mathrm{~mL})$. The combined organic layers were washed with brine, dried over $\mathrm{MgSO}_{4}$ filtrated over cotton wool and concentrated under vacuum using a rotary evaporator to give the crude product. This was purified by column chromatography, using PET-EtOAc (99:1) to give the title product rac-3 as an orange oil (12.9 $\mathrm{g}, 97 \%)$.

$v_{\max }\left(\right.$ film) $/ \mathrm{cm}^{-1} 2961,2866,1626,1442,1368,1326,1274,1244,1150$, 1034, 830, 809, 756.

${ }^{1} \mathrm{H} \mathrm{NMR}\left(500 \mathrm{MHz}, \mathrm{CDCl}_{3}\right): \delta(\mathrm{ppm}) 4.51(\mathrm{~s}, 1 \mathrm{H}, \mathrm{FcH}), 4.40(\mathrm{~s}, 1 \mathrm{H}, \mathrm{FcH})$ $4.38(\mathrm{~s}, 1 \mathrm{H}, \mathrm{FcH}), 4.29$ (s, 1H, H5), $4.28(\mathrm{~s}, 1 \mathrm{H}, \mathrm{FcH}), 4.25$ (s, 1H, H4), 4.08 (s, 1H, H3), 3.98 (br s, $1 \mathrm{H}, \mathrm{CH}$ ), 3.38 (br s, $1 \mathrm{H}, \mathrm{CH}), 1.46$ (br s, 6H, $2 \times \mathrm{CH}_{3}$ ) 1.07 (br s, 6H, $\left.2 \times \mathrm{CH}_{3}\right), 0.26\left(\mathrm{~s}, 9 \mathrm{H}, \mathrm{Si}\left(\mathrm{CH}_{3}\right)_{3}\right)$.

${ }^{13} \mathrm{C}$ NMR (126 MHz, $\left.\mathrm{CDCl}_{3}\right): \delta(\mathrm{ppm}) 168.2$ (C=0), 93.5 (C1), 77.4 (C3), 76.7 ( FcCH), $75.6(\mathrm{C} 2), 75.3(\mathrm{FcCH}), 73.9(\mathrm{C} 4), 73.6(\mathrm{C} 5), 72.1(\mathrm{FcCH}), 71.6$ ( $\mathrm{FcCH}), 50.3(\mathrm{CH}), 45.8(\mathrm{CH}), 40.4\left(\mathrm{C1}^{\prime}\right), 21.2\left(2 \times \mathrm{CH}_{3}\right), 20.8\left(2 \mathrm{x} \mathrm{CH}_{3}\right), 0.7$ $\left(\mathrm{Si}\left(\mathrm{CH}_{3}\right)_{3}\right)$.

Mass: 511 [M], 496 [M-CH3].

\section{1'-Iodo- $N, N$-diisopropylferrocenecarboxamide (4)}

[CAS Reg. No. 2407448-99-9]
Potassium tert-butoxide (5.72 g, $51.0 \mathrm{mmol}, 2.00$ equiv) was added to a solution of rac-3 (13.0 g, $25.5 \mathrm{mmol}, 1.00$ equiv) in DMSO (76.5 mL) and the reaction mixture was stirred for $10 \mathrm{~min}$ at rt. Cold water $(200 \mathrm{~mL})$ was added to the reaction mixture which was extracted with EtOAc $(4 \times 70$ $\mathrm{mL})$. The combined organic layers were washed with brine $(4 \times 50 \mathrm{~mL})$, dried over $\mathrm{MgSO}_{4}$, filtrated over cotton wool and concentrated under vacuum using a rotary evaporator to give the crude product. This was purified by column chromatography, using PET-EtOAc $(85: 15)$ to give the title product 4 as an orange solid ( $9.92 \mathrm{~g}, 88 \%)$.

Mp 58-60 ${ }^{\circ} \mathrm{C}$.

$v_{\max }($ film $) / \mathrm{cm}^{-1} 2964,1615,1459,1368,1315,1201,1043,1029,862$, $825,804,762$

${ }^{1} \mathrm{H}$ NMR $\left(300 \mathrm{MHz}, \mathrm{CDCl}_{3}\right): \delta(\mathrm{ppm}) 4.49(\mathrm{t}, J=1.9 \mathrm{~Hz}, 2 \mathrm{H}, \mathrm{H} 2+\mathrm{H} 5), 4.46$ (br s, 1H, CH), $4.41\left(\mathrm{t}, J=1.9 \mathrm{~Hz}, 2 \mathrm{H}, \mathrm{H} 2^{\prime}+\mathrm{H}^{\prime}\right), 4.26-4.24(\mathrm{~m}, 4 \mathrm{H}, \mathrm{H} 3+\mathrm{H} 4$ + H3' + H4'), 3.41 (br s, 1H, CH), 1.47 (br s, 6H, 2 x CH3), 1.21 (br s, 6H, 2 x $\mathrm{CH}_{3}$ ).

${ }^{13} \mathrm{C}$ NMR (75 MHz, $\left.\mathrm{CDCl}_{3}\right): \delta(\mathrm{ppm}) 168.5$ (C=0), 83.5 (C1), $76.5\left(\mathrm{C}^{\prime}+\mathrm{C}^{\prime}\right)$, 73.1 (C2 + C5), 72.2 (C3 + C4), $71.3\left(\mathrm{C}^{\prime}+\mathrm{C}^{\prime}\right), 49.8(\mathrm{CH}), 46.4(\mathrm{CH}), 40.1$ (C1'), $21.3\left(4 \times \mathrm{CH}_{3}\right)$.

Mass: 439 [M], 339 [M-NiPr 2 .

\section{1-( $N, N$-Diisopropylaminomethyl)-1'-iodoferrocene (5)}

$\mathrm{NaBH}_{4}$ (2.84 g, 75.0 mmol, 5.00 equiv) was introduced into a flame-dried round-bottom flask equipped with a bubbler, and THF $(75.0 \mathrm{~mL})$ was added before the reaction mixture was cooled to $0^{\circ} \mathrm{C}$. Iodine $(9.14 \mathrm{~g}, 36.0$ mmol, 2.40 equiv) was introduced into a separate flame-dried roundbottom flask under argon and was dissolved into anhydrous THF (30.0 $\mathrm{mL}$ ). The iodine solution was transferred into the $\mathrm{NaBH}_{4}$ suspension dropwise by cannula. Remark: vigorous evolution of hydrogen occurred during the addition. After addition, the reaction mixture was allowed to warm to rt out of the cooling bath and was stirred for $1 \mathrm{~h}$, giving a colorless solution of $\mathrm{BH}_{3}$.THF. Compound 4 (6.60 g, $15.0 \mathrm{mmol}, 1.00$ equiv) was then added portionwise to the $\mathrm{BH}_{3}$.THF solution which was then stirred overnight at reflux Remark: the use of PTFE sleeve is strongly recommended to avoid blockage of the ground glass joints. The reaction mixture was cooled to $0{ }^{\circ} \mathrm{C}$ and a solution of $\mathrm{NaOH}(10 \%, 75 \mathrm{~mL})$ was added dropwise. Caution: as a vigorous evolution of gas was noticed, the first drops of $\mathrm{NaOH}$ solution should be added slowly. After addition, the reaction mixture was stirred at reflux for $1 \mathrm{~h}$. The reaction mixture was cooled to rt and the layers were separated. The aqueous layer was further extracted with EtOAc $(2 \times 50 \mathrm{~mL})$. The combined organic layers were extracted with $\mathrm{HCl}(1.0 \mathrm{M}$ aq., $3 \times 50 \mathrm{~mL})$. The combined aqueous layers were washed with $\mathrm{Et}_{2} \mathrm{O}(2 \times 50 \mathrm{~mL})$ and basified with solid $\mathrm{K}_{2} \mathrm{CO}_{3}$ until pH 8 was reached. The mixture was extracted with EtOAc $(2 \times 60 \mathrm{~mL})$ and the combined organic layers were dried over MgSO4, filtrated on celite (washed with EtOAc until the filtrate was colorless), and concentrated under vacuum using a rotary evaporator to give the pure product $\mathbf{5}$ as an orange oil $(6.08 \mathrm{~g}, 95 \%)$.

$v_{\max }\left(\right.$ film) $/ \mathrm{cm}^{-1} 3090,2961,1684,1461,1380,1360,1200,1164,1136$, $1115,1018,861,823,807$

${ }^{1} \mathrm{H}$ NMR (300 MHz, CDCl $): \delta(\mathrm{ppm}) 4.31\left(\mathrm{t}, J=1.6 \mathrm{~Hz}, 2 \mathrm{H}, \mathrm{H} 2^{\prime}+\mathrm{H} 5^{\prime}\right), 4.15$ $(\mathrm{t}, J=1.6 \mathrm{~Hz}, 2 \mathrm{H}, \mathrm{H} 2+\mathrm{H} 5), 4.10\left(\mathrm{~d}, J=1.6 \mathrm{~Hz}, 2 \mathrm{H}, \mathrm{H} 3^{\prime}+\mathrm{H} 4^{\prime}\right), 4.09(\mathrm{~d}, J=$ $1.6 \mathrm{~Hz}, 2 \mathrm{H}, \mathrm{H} 3+\mathrm{H} 4), 3.47\left(\mathrm{~s}, 2 \mathrm{H}, \mathrm{CH}_{2}\right), 3.04$ (sept, $J=6.7 \mathrm{~Hz}, 2 \mathrm{H}, 2 \mathrm{x} \mathrm{CH}$ ), $1.02\left(\mathrm{~d}, J=6.7 \mathrm{~Hz}, 12 \mathrm{H}, 4 \times \mathrm{CH}_{3}\right)$

${ }^{13} \mathrm{C}$ NMR (75 MHz, $\left.\mathrm{CDCl}_{3}\right): \delta(\mathrm{ppm}) 90.4(\mathrm{C} 1), 75.1\left(\mathrm{C}^{\prime}{ }^{\prime}+\mathrm{C}^{\prime}\right), 72.9(\mathrm{C} 2+$ C5), 70.6 (C3 + C4), $69.4\left(\mathrm{C}^{\prime}+\mathrm{C}^{\prime}\right), 47.7(2 \times \mathrm{CH}), 43.4\left(\mathrm{CH}_{2}\right), 41.0\left(\mathrm{C}^{\prime}\right)$, $21.0\left(4 \times \mathrm{CH}_{3}\right)$.

Mass: 439 [M], 339 [M-NiPr 2$].$

\section{1-(Acetoxymethyl)-1'-iodoferrocene (6)}

Compound 5 ( $8.53 \mathrm{~g}, 20.0 \mathrm{mmol}, 1.00$ equiv) was dissolved into acetic anhydride (76.2 mL, $82.3 \mathrm{~g}, 800 \mathrm{mmol}, 40.0$ equiv) at rt and the resulting solution was stirred at $160{ }^{\circ} \mathrm{C}$ in a pre-heated bath for $1 \mathrm{~h}$. The reaction mixture was cooled to $0^{\circ} \mathrm{C}$ and EtOAc $(150 \mathrm{~mL})$ was added before pouring the reaction mixture onto ice $(200 \mathrm{~mL})$. Solid $\mathrm{K}_{2} \mathrm{CO}_{3}$ was added under stirring until pH 8 was reached. Caution: small portions of $\mathrm{K}_{2} \mathrm{CO}_{3}$ should be added each time as vigorous evolution of gas occurred. The layers were separated and the aqueous layer was extracted with EtOAc $(1 \times 75 \mathrm{~mL})$. The combined organic layers were washed with water $(1 \times 75 \mathrm{~mL})$, brine (1 x $50 \mathrm{~mL}$ ), dried over $\mathrm{MgSO}_{4}$, filtrated over cotton wool and concentrated under vacuum using a rotary evaporator to give the crude product. This was purified by column chromatography over $\mathrm{SiO}_{2}$, using PET/EtOAc (95:5) to give the title product 6 as an orange solid (6.75 g, $88 \%)$.

Mp $54-56^{\circ} \mathrm{C}$. 
$v_{\max }\left(\right.$ film) $/ \mathrm{cm}^{-1} 3090,2961,1684,1461,1380,1360,1200,1164,1136$ $1115,1018,861,823,807$.

${ }^{1} \mathrm{H}$ NMR (500 MHz, $\left.\mathrm{CDCl}_{3}\right): \delta(\mathrm{ppm}) 4.91\left(\mathrm{~s}, 2 \mathrm{H}, \mathrm{CH}_{2}\right), 4.39(\mathrm{t}, J=1.7 \mathrm{~Hz}, 2 \mathrm{H}$ $\left.\mathrm{H} 2^{\prime}+\mathrm{H} 5^{\prime}\right), 4.22(\mathrm{~m}, 2 \mathrm{H}, \mathrm{H} 3+\mathrm{H} 4), 4.21(\mathrm{~m}, 2 \mathrm{H}, \mathrm{H} 2+\mathrm{H} 5), 4.15(\mathrm{t}, J=1.7 \mathrm{~Hz}$ $\left.2 \mathrm{H}, \mathrm{H} 34+\mathrm{H}^{\prime}\right), 2.05\left(\mathrm{~s}, 3 \mathrm{H}, \mathrm{CH}_{3}\right)$.

${ }^{13} \mathrm{C}$ NMR (125 MHz, $\mathrm{CDCl}_{3}$ ): $\delta(\mathrm{ppm}) 170.9$ (C=0), 82.9 (C1), 75.3 (C2' + C5'), 72.6 (C3 + C4), $72.0(\mathrm{C} 2+\mathrm{C} 5), 69.5\left(\mathrm{C}^{\prime}+\mathrm{C}^{\prime}\right), 62.2\left(\mathrm{CH}_{2}\right), 39.9\left(\mathrm{C} 1^{\prime}\right)$ $21.1\left(\mathrm{CH}_{3}\right)$.

Mass: 439 [M], 339 [M-NiPr2].

\section{1-Iodo-1'-methylferrocene (7)}

[CAS Reg. No. 31833-00-8]

Compound 6 (384.0 mg, $1.0 \mathrm{mmol}, 1.0$ equiv) was added portionwise to a solution of $\mathrm{BH}_{3}$ in THF $(1.0 \mathrm{M}, 5.00 \mathrm{~mL}, 5.00 \mathrm{mmol}, 5.00$ equiv) at rt before the reaction mixture was heated at reflux overnight. Remark: the use of PTFE sleeve is strongly recommended to avoid blockage of the ground glass joints. The reaction mixture was cooled to $0{ }^{\circ} \mathrm{C}$ and a solution of $\mathrm{NaOH}(10 \%, 10 \mathrm{~mL})$ was added dropwise. Caution: as a vigorous evolution of gas occurs, the first drops of $\mathrm{NaOH}$ solution should be added slowly. After addition, the reaction mixture was stirred at reflux for $1 \mathrm{~h}$. The reaction mixture was cooled to $r t$ and the layers were separated. The aqueous layer was extracted with EtOAc $(1 \times 10 \mathrm{~mL})$. The combined organic layers were washed with water $(1 \times 10 \mathrm{~mL})$, brine $(1 \times 10 \mathrm{~mL})$ dried over $\mathrm{MgSO}_{4}$, filtrated over cotton wool and concentrated under vacuum using a rotary evaporator to give the crude product. This was purified by column chromatography over $\mathrm{SiO}_{2}$, using PET/EtOAc (95:5) to give the title product 7 as an orange oil (300 mg, 92\%).

$v_{\max }\left(\right.$ film) $/ \mathrm{cm}^{-1} 3087,2918,1476,1453,1403,1382,1368,1342,1227$, 1144, 1039, 1022, 860, 822, 804.

${ }^{1} \mathrm{H}$ NMR (500 MHz, $\left.\mathrm{CDCl}_{3}\right): \delta(\mathrm{ppm}) 4.31(\mathrm{t}, J=1.6 \mathrm{~Hz}, 2 \mathrm{H}, \mathrm{H} 2+\mathrm{H} 5), 4.11$ $(\mathrm{t}, J=1.6 \mathrm{~Hz}, 2 \mathrm{H}, \mathrm{H} 3+\mathrm{H} 4), 4.09\left(\mathrm{t}, J=1.7 \mathrm{~Hz}, 2 \mathrm{H}, \mathrm{H} 3^{\prime}+\mathrm{H}^{\prime}\right), 4.04(\mathrm{t}, J=1.7$ $\left.\mathrm{Hz}, 2 \mathrm{H}, \mathrm{H} 2^{\prime}+\mathrm{H}^{\prime}\right), 2.01\left(\mathrm{~s}, 3 \mathrm{H}, \mathrm{CH}_{3}\right)$.

${ }^{13} \mathrm{C}$ NMR (125 MHz, $\left.\mathrm{CDCl}_{3}\right): \delta(\mathrm{ppm}) 85.7$ (C1'), $75.2(\mathrm{C} 2+\mathrm{C} 5), 72.4\left(\mathrm{C}^{\prime}+\right.$ $\left.\mathrm{C}^{\prime}\right), 70.3\left(\mathrm{C}^{\prime}+\mathrm{C}^{\prime}\right), 69.5(\mathrm{C} 3+\mathrm{C} 4), 40.9(\mathrm{C} 1), 14.2\left(\mathrm{CH}_{3}\right)$.

Mass: 326 [M].

\section{1'-Iodoferrocenemethanol (8)}

[CAS Reg. No. 224456-53-5]

$\mathrm{NaOH}$ (2.04 g, 51.0 mmol, 3.00 equiv) was dissolved in $\mathrm{H}_{2} \mathrm{O}(55.0 \mathrm{~mL})$ and a solution of compound 6 ( $6.50 \mathrm{~g}, 17.0 \mathrm{mmol}, 1.00$ equiv) in THF ( $30.0 \mathrm{~mL})$ was added at rt. The reaction mixture was heated at $80^{\circ} \mathrm{C}$ for $2 \mathrm{~h}$ in a preheated bath. The reaction mixture was cooled to $\mathrm{rt}$ and layers were separated. The aqueous layer was extracted with EtOAc $(2 \times 20 \mathrm{~mL})$. The combined organic layers were dried over $\mathrm{MgSO}_{4}$, filtrated over cotton wool and concentrated under vacuum using a rotary evaporator to give the crude product. This was purified by column chromatography over $\mathrm{SiO}_{2}$, using PET/EtOAc (95:5) to give the title product 8 as an orange solid (5.23 g, 90\%). Analytical data analogous to those reported previously. ${ }^{13}$ Mp 58-60 ${ }^{\circ} \mathrm{C}$.

$v_{\max }($ film $) / \mathrm{cm}^{-1} 3325,3097,2925,2863,1402,1379,1343,1235,1143$ 1040, 996, 922, 862, 825, 738 .

${ }^{1} \mathrm{H}$ NMR (500 MHz, $\left.\mathrm{CDCl}_{3}\right): \delta(\mathrm{ppm}) 4.40-4.39\left(\mathrm{~m}, 4 \mathrm{H}, \mathrm{H} 2^{\prime}+\mathrm{H}^{\prime}{ }^{\prime}+\mathrm{CH}_{2}\right)$ 4.19 (s, 4H, H2 + H3 + H4 + H5), 4.16 (t, J=1.8 Hz, 2H, H3' + H4'), 1.78 (br $\mathrm{s}, 1 \mathrm{H}, \mathrm{OH})$.

${ }^{13} \mathrm{C}$ NMR (125 MHz, $\left.\mathrm{CDCl}_{3}\right): \delta(\mathrm{ppm}) 89.6(\mathrm{C} 1), 75.0\left(\mathrm{C}^{\prime}+\mathrm{C}^{\prime}\right), 71.4(\mathrm{C} 2+$ C5 or C3 + C4), $70.9\left(\mathrm{C} 2+\mathrm{C} 5\right.$ or C3 + C4), $69.3\left(\mathrm{C}^{\prime}+\mathrm{C}^{\prime}\right), 60.3\left(\mathrm{CH}_{2}\right), 40.1$ (C1').

\section{Mass: $342[\mathrm{M}], 264$}

\section{1-Iodo-1'-(methoxymethyl)ferrocene (9)}

Sodium hydride ( $60 \%$ dispersion in oil, $120 \mathrm{mg}, 3.00 \mathrm{mmol}, 3.00$ equiv) was added portionwise to a solution of compound $8(342 \mathrm{mg}, 1.00 \mathrm{mmol}$, 1.00 equiv) in THF ( $5.00 \mathrm{~mL})$ at $0{ }^{\circ} \mathrm{C}$. After addition, the cooling bath was removed and the reaction mixture was stirred for $1 \mathrm{~h}$ at $\mathrm{rt}$. The reaction mixture was cooled to $0{ }^{\circ} \mathrm{C}$ and iodomethane $(250 \mu \mathrm{L}, 568 \mathrm{mg}, 4.00 \mathrm{mmol}$, 4.00 equiv) was added dropwise. After addition, the cooling bath was removed and the reaction mixture was stirred for $1 \mathrm{~h}$ at $\mathrm{rt}$. The reaction mixture was cooled to $0{ }^{\circ} \mathrm{C}$ and $\mathrm{NH}_{4} \mathrm{Cl}$ (aq. sat., $10 \mathrm{~mL}$ ) was added dropwise. EtOAc $(10 \mathrm{~mL})$ was added and the layers were separated. The aqueous layer was extracted with EtOAc $(10 \mathrm{~mL})$ and the combined organic layers were dried over $\mathrm{MgSO}_{4}$, filtrated over cotton wool and concentrated under vacuum using a rotary evaporator to give the crude product. This was purified by column chromatography over $\mathrm{SiO}_{2}$, using
PET/EtOAc (80:20) to give the title product 9 as an orange oil (346 mg, 97\%).

$v_{\max }\left(\right.$ film) $/ \mathrm{cm}^{-1} 3089,2920,2887,2813,1447,1402,1379,1344,1234$, $1187,1175,1085,1038,1021,899,862,824,809$.

${ }^{1} \mathrm{H} \mathrm{NMR}\left(500 \mathrm{MHz} \mathrm{CDCl}_{3}\right): \delta(\mathrm{ppm}) 4.36(\mathrm{~s}, 2 \mathrm{H}, \mathrm{H} 2+\mathrm{H} 5), 4.25\left(\mathrm{~s}, 2 \mathrm{H}, \mathrm{CH}_{2}\right)$, 4.19 (s, 4H, H2' + H3' + H4' + H5'), $4.13(\mathrm{~s}, 2 \mathrm{H}, \mathrm{H} 3+\mathrm{H} 4), 3.34\left(\mathrm{~s}, 3 \mathrm{H}, \mathrm{CH}_{3}\right)$.

${ }^{13} \mathrm{C}$ NMR (125 MHz, $\left.\mathrm{CDCl}_{3}\right): \delta(\mathrm{ppm}) 84.8\left(\mathrm{C}^{\prime}\right), 75.1(\mathrm{C} 2+\mathrm{C} 5), 72.4\left(\mathrm{C} 2{ }^{\prime}+\right.$ $\mathrm{C}^{\prime}$ or $\left.\mathrm{C}^{\prime}+\mathrm{C}^{\prime}\right), 71.7\left(\mathrm{C}^{\prime}+\mathrm{C}^{\prime}\right.$ or $\left.\mathrm{C}^{\prime}+\mathrm{C}^{\prime}\right), 70.2\left(\mathrm{CH}_{2}\right), 69.4(\mathrm{C} 3+\mathrm{C} 4)$, $57.9\left(\mathrm{CH}_{3}\right), 40.1(\mathrm{C} 1)$.

Mass: $356[\mathrm{M}]$.

\section{1'-Iodoferrocenecarboxaldehyde (10)}

[CAS Reg. No. 176100-20-2]

$\mathrm{N}$-Methylmorpholine- $\mathrm{N}$-oxide (NMO; $5.04 \mathrm{~g}, 43.0 \mathrm{mmol}, 3.50$ equiv) was placed in a Schlenk tube which was heated at $90^{\circ} \mathrm{C}$ under high vacuum for $3 \mathrm{~h}$ before being cooled to rt. In a separate Schlenk tube, compound 8 (4.22 $\mathrm{g}, 12.3 \mathrm{mmol}, 1.00$ equiv) was dissolved in acetone $(120 \mathrm{~mL})$ and this solution was cannulated onto $\mathrm{NMO}$. $\mathrm{RuCl}_{2}\left(\mathrm{PPh}_{3}\right)_{3}(589 \mathrm{mg}, 0.61 \mathrm{mmol}$, 0.05 equiv) was added in one portion and the reaction mixture was stirred at $\mathrm{rt}$ for $1 \mathrm{~h}$, shielded from light. The reaction mixture was concentrated under vacuum using a rotary evaporator. $\mathrm{HCl}(1.0 \mathrm{M}$ aq., $40 \mathrm{~mL})$ was added and the reaction mixture was extracted with EtOAc $(3 \times 30 \mathrm{~mL})$. The combined organic layers were dried over $\mathrm{MgSO}_{4}$, filtrated over cotton wool and concentrated under vacuum using a rotary evaporator to give the crude product. This was purified by column chromatography over $\mathrm{SiO}_{2}$, using PET/EtOAc $(80: 20)$ with $1 \%$ of $\mathrm{NEt}_{3}$ to give the title product 10 as a red solid $(3.57 \mathrm{~g}, 85 \%)$. Analytical data analogous to those reported previously. ${ }^{13}$

Mp 31-33 ${ }^{\circ} \mathrm{C}$.

$v_{\max }(\mathrm{film}) / \mathrm{cm}^{-1}$ 3096, 2801, 2761, 1673, 1658, 1455, 1368, 1343, 1242 1026, 824, 740 .

$\left.{ }^{1} \mathrm{H} \mathrm{NMR} \mathrm{(300} \mathrm{MHz,} \mathrm{CDCl} 3\right): \delta(\mathrm{ppm}) 10.00(\mathrm{~s}, 1 \mathrm{H}, \mathrm{CHO}), 4.77(\mathrm{t}, J=2.0 \mathrm{~Hz}$, $2 \mathrm{H}, \mathrm{H} 2+\mathrm{H} 5), 4.59(\mathrm{t}, J=2.0 \mathrm{~Hz}, 2 \mathrm{H}, \mathrm{H} 3+\mathrm{H} 4), 4.50\left(\mathrm{t}, J=1.9 \mathrm{~Hz}, 2 \mathrm{H}, \mathrm{H} 2^{\prime}+\right.$ $\left.\mathrm{H}^{\prime}\right), 4.26$ (t, $\left.J=1.9 \mathrm{~Hz}, 2 \mathrm{H}, \mathrm{H} 3^{\prime}+\mathrm{H} 4^{\prime}\right)$.

${ }^{13} \mathrm{C}$ NMR (125 MHz, $\mathrm{CDCl}_{3}$ ): $\delta(\mathrm{ppm}) 193.4(\mathrm{CHO}), 80.6(\mathrm{C} 1), 76.4(\mathrm{C} 3+$ C4), $76.3\left(\mathrm{C} 2^{\prime}+\mathrm{C}^{\prime}\right), 72.4(\mathrm{C} 2+\mathrm{C} 5), 70.6\left(\mathrm{C}^{\prime}+\mathrm{C}^{\prime}\right), 39.4\left(\mathrm{C}^{\prime}\right)$.

\section{1-(Hydroxy(phenyl)methyl)-1'-iodoferrocene (11)}

A solution of phenylmagnesium bromide in THF $(0.90 \mathrm{M}, 2.10 \mathrm{~mL}, 1.90$ mmol, 0.95 equiv) was added dropwise to a solution of compound $10(680$ $\mathrm{mg}, 2.00 \mathrm{mmol}, 1.00$ equiv) in THF $(20.0 \mathrm{~mL})$ at $-78^{\circ} \mathrm{C}$. Keeping the flask in the cooling bath, the reaction mixture was allowed to warm slowly to $40{ }^{\circ} \mathrm{C}$ and the progress of the reaction was monitored by TLC. After consumption of the starting material, $\mathrm{NH}_{4} \mathrm{Cl}$ (sat. aq., $20 \mathrm{~mL}$ ) was added and the reaction mixture was warmed to $\mathrm{rt}$ before being extracted with EtOAc $(2 \times 20 \mathrm{~mL})$. The combined organic layers were dried over $\mathrm{MgSO}_{4}$, filtrated over cotton wool and concentrated under vacuum using a rotary evaporator to give the crude product. This was purified by column chromatography over $\mathrm{SiO}_{2}$, using PET/EtOAc $(80: 20)$ to give the title product 11 as a red solid ( $812 \mathrm{mg}, 97 \%)$. Splitting of some ferrocene peaks was noticed in both ${ }^{1} \mathrm{H}$ and ${ }^{13} \mathrm{C}$ NMR spectrum as previously observed in chiral ferrocenemethanol derivatives. ${ }^{41}$

Mp 76-78 ${ }^{\circ} \mathrm{C}$.

$v_{\max }\left(\right.$ film) $/ \mathrm{cm}^{-1} 3470,1490,1449,1377,1179,1047,1018,806,716$

${ }^{1} \mathrm{H}$ NMR (500 MHz, $\mathrm{CDCl}_{3}$ ): $\delta$ (ppm) 7.40-7.28 (m, 2H, H2" + H6"), 7.357.32 (m, 2H, H3" + H5"), 7.28-7.26 (m, 1H, H4"), 5.59 (d, $J=3.2 \mathrm{~Hz}, 1 \mathrm{H}$ $\mathrm{CH}), 4.46\left(\mathrm{~m}, 1 \mathrm{H}, \mathrm{H} 2^{\prime}\right.$ or $\left.\mathrm{H}^{\prime}\right), 4.45$ (m, 1H, H2' or H5'), 4.27 (dd, $J=1.8,3.3$ $\mathrm{Hz}, 1 \mathrm{H}, \mathrm{H} 2$ or H5), 4.21 (m, 2H, H3 + H4), 4.19 (m, 2H, H3' + H4'), 4.14 (dd, $J=1.8,3.3 \mathrm{~Hz}, 1 \mathrm{H}$; $\mathrm{H} 2$ or $\mathrm{H} 5), 2.44(\mathrm{~d}, J=3.3 \mathrm{~Hz}, 1 \mathrm{H}, \mathrm{OH})$.

${ }^{1} \mathrm{H}$ NMR (500 MHz, DMSO-d 6 ): $\delta$ (ppm) 7.38 (d, $J=7.7 \mathrm{~Hz}, 2 \mathrm{H}, \mathrm{H2} "$ + H6"), 7.31 (t, $\left.J=7.7 \mathrm{~Hz}, 2 \mathrm{H}, \mathrm{H} 3^{\prime \prime}+\mathrm{H} 5^{\prime \prime}\right), 7.22$ (t, $\left.J=7.7 \mathrm{~Hz}, 1 \mathrm{H}, \mathrm{H} 4^{\prime \prime}\right), 5.50-5.48$ $(\mathrm{m}, 2 \mathrm{H}, \mathrm{OH}+\mathrm{CH}), 4.44(\mathrm{~m}, 1 \mathrm{H}, \mathrm{FcCH}), 4.40(\mathrm{~m}, 1 \mathrm{H}, \mathrm{FcCH}), 4.27(\mathrm{~m}, 1 \mathrm{H}$, $\mathrm{FcCH}), 4.18(\mathrm{~m}, 2 \mathrm{H}, \mathrm{FcCH}), 4.08(\mathrm{~m}, 1 \mathrm{H}, \mathrm{FcCH}), 4.06(\mathrm{~m}, 1 \mathrm{H}, \mathrm{FcCH}), 3.94$ (m, $1 \mathrm{H}, \mathrm{FcCH})$.

${ }^{13} \mathrm{C}$ NMR (125 MHz, $\mathrm{CDCl}_{3}$ ): $\delta$ (ppm) 143.4 (C1"), 128.4 (C3" + C5"), 127.7 (C4"), 126.4 (C2" + C6"), 95.2 (C1), 75.3 (C2' or C5'), 75.2 (C2' or C5'), 71.9 (CH), 71.5 (C3 or C4), 71.3 (C3 or C4), 70.3 (C2 or C5), 69.6 (C3' or $\mathrm{C}^{\prime}$ ), 69.5 (C3' or C4'), 68.9 (C2 or C5), 40.1 (C1').

\section{1-Benzoyl-1'-iodoferrocene (12)}

[CAS Reg. No. 1884149-19-2]

$N$-Methylmorpholine- $N$-oxide (NMO; $351 \mathrm{mg}, 3.00 \mathrm{mmol}, 3.00$ equiv) was placed in a Schlenk tube which was heated at $90^{\circ} \mathrm{C}$ under high vacuum for $3 \mathrm{~h}$ before being cooled to $\mathrm{rt}$. In a separate Schlenk tube, compound $\mathbf{1 1}$ 
(418 mg, $1.00 \mathrm{mmol}, 1.00$ equiv) was dissolved in acetone $(10.0 \mathrm{~mL}$ ) and this solution was cannulated onto $\mathrm{NMO} . \mathrm{RuCl}_{2}\left(\mathrm{PPh}_{3}\right)_{3}(47.9 \mathrm{mg}, 50.0 \mu \mathrm{mol}$, 0.05 equiv) was added in one portion and the reaction mixture was stirred at $\mathrm{rt}$ for $1 \mathrm{~h}$, shielded from light. Volatiles were removed under vacuum using a rotary evaporator. The reaction mixture was concentrated under vacuum using a rotary evaporator. $\mathrm{HCl}(1.0 \mathrm{M}$ aq., $20 \mathrm{~mL})$ was added and the reaction mixture was extracted with EtOAc $(2 \times 20 \mathrm{~mL})$. The combined organic layers were dried over $\mathrm{MgSO}_{4}$, filtrated over cotton wool and concentrated under vacuum using a rotary evaporator to give the crude product. This was purified by column chromatography over $\mathrm{SiO}_{2}$, using PET/EtOAc $(80: 20)$ with $1 \%$ of $\mathrm{NEt}_{3}$ to give the title product 12 as a red oil (400 mg, 96\%). Analytical data analogous to those reported previously. ${ }^{10 \mathrm{~b}}$

$v_{\max }\left(\right.$ film) $/ \mathrm{cm}^{-1} 1635,1447,1438,1374,1282,1168,1048,1024,852$, $828,797,724$.

${ }^{1} \mathrm{H}$ NMR (500 MHz, $\mathrm{CDCl}_{3}$ ): $\delta(\mathrm{ppm}) 7.88$ (d, J= 7.2 Hz, 2H, H2" + H6"), 7.55 $\left(\mathrm{t}, J=7.2 \mathrm{~Hz}, 1 \mathrm{H}, \mathrm{H} 4^{\prime \prime}\right), 7.47\left(\mathrm{t}, J=7.6 \mathrm{~Hz}, 2 \mathrm{H}, \mathrm{H} 3^{\prime \prime}+\mathrm{H} 5{ }^{\prime \prime}\right), 4.90(\mathrm{t}, J=1.9 \mathrm{~Hz}$ $2 \mathrm{H}, \mathrm{H} 2+\mathrm{H} 5), 4.55(\mathrm{t}, J=1.9 \mathrm{~Hz}, 2 \mathrm{H}, \mathrm{H} 3+\mathrm{H} 4), 4.41\left(\mathrm{t}, J=1.8 \mathrm{~Hz}, 2 \mathrm{H}, \mathrm{H} 2^{\prime}+\right.$ $\left.\mathrm{H} 5^{\prime}\right), 4.19\left(\mathrm{t}, J=1.8 \mathrm{~Hz}, 2 \mathrm{H}, \mathrm{H} 3^{\prime}+\mathrm{H}^{\prime}\right)$.

${ }^{13} \mathrm{C}$ NMR (125 MHz, $\mathrm{CDCl}_{3}$ ): $\delta$ (ppm) 198.2 (C=0), 139.6 (C1"), 131.8 (C4") 128.4 (C3" + C5"), 128.3 (C2"' + C6"), 79.7 (C1), 76.6 (C2' + C5'), 76.1 (C3 + C4), 74.0 (C2 + C5), $71.4\left(\mathrm{C}^{\prime}+\mathrm{C}^{\prime}\right), 40.0\left(\mathrm{C} 1^{\prime}\right)$.

\section{1'-Iodoferrocenecarbonitrile (13)}

[CAS Reg. No. 32876-20-3]

Compound 10 (0.68 g, $2.00 \mathrm{mmol}$, 1.00 equiv), hydroxylamine hydrochloride ( $181 \mathrm{mg}, 2.60 \mathrm{mmol}, 1.30$ equiv), potassium iodide $(0.53 \mathrm{~g}$, $2.00 \mathrm{mmol}, 1.00$ equiv) and zinc oxide ( $0.16 \mathrm{mg}, 2.00 \mathrm{mmol}, 1.00$ equiv) were introduced in a Schlenk tube which was subjected to three cycles of vacuum/argon. Acetonitrile $(10.0 \mathrm{~mL})$ was added and the reaction mixture was stirred at $80^{\circ} \mathrm{C}$ for $2 \mathrm{~h}$. The reaction mixture was cooled to $\mathrm{rt}$ and $5 \% \mathrm{Na}_{2} \mathrm{~S}_{2} \mathrm{O}_{3}(2.00 \mathrm{~mL})$ was added and stirring was continued for 5 min. The reaction mixture was filtrated and the resulting solids were washed with EtOAc $(10 \mathrm{~mL})$. Water $(10 \mathrm{~mL})$ was added to the combined filtrates which were extracted with EtOAc $(3 \times 15 \mathrm{~mL})$. The combined organic layers were washed with brine, dried over $\mathrm{MgSO}_{4}$, filtrated over cotton wool and concentrated under vacuum using a rotary evaporator to give the crude product. This was purified by column chromatography, using PET-EtOAc (90:10) to give the title product $\mathbf{1 3}$ as a dark red solid (0.61 g, 91\%)

Mp $39-41^{\circ} \mathrm{C}$.

$\nu_{\max }($ film $) / \mathrm{cm}^{-1} 3101,3087,2224,1406,1381,1346,1233,1023,865$, 845,812 .

${ }^{1} \mathrm{H}$ NMR (500 MHz, $\left.\mathrm{CDCl}_{3}\right): \delta(\mathrm{ppm}) 4.62(\mathrm{t}, J=1.9 \mathrm{~Hz}, 2 \mathrm{H}, \mathrm{H} 2+\mathrm{H} 5), 4.55$ $\left(\mathrm{t}, J=1.9 \mathrm{~Hz}, 2 \mathrm{H}, \mathrm{H} 2^{\prime}+\mathrm{H} 5^{\prime}\right), 4.39(\mathrm{t}, J=1.9 \mathrm{~Hz}, 2 \mathrm{H}, \mathrm{H} 3+\mathrm{H} 4), 4.34(\mathrm{t}, J=1.9$ $\left.\mathrm{Hz}, 2 \mathrm{H}, \mathrm{H} 3^{\prime}+\mathrm{H} 4^{\prime}\right)$.

${ }^{13} \mathrm{C}$ NMR (125 MHz, $\left.\mathrm{CDCl}_{3}\right): \delta(\mathrm{ppm}) 119.2(\mathrm{C} \equiv \mathrm{N}), 77.0\left(\mathrm{C}^{\prime}+\mathrm{C}^{\prime}\right), 74.4$ (C2 + C5), $74.2(\mathrm{C} 3+\mathrm{C} 4), 71.7\left(\mathrm{C}^{\prime}+\mathrm{C} 4^{\prime}\right), 54.1(\mathrm{C} 1), 39.8\left(\mathrm{C}^{\prime}\right)$.

Mass: 337 [M], 210 [M-I], 183

\section{Methyl 1'-iodoferrocenecarboxylate (14)}

[CAS Reg. No. 31869-23-5]

Potassium hydroxide ( $2.53 \mathrm{~g}, 45.0 \mathrm{mmol}, 6.00$ equiv) was added to a solution of compound 10 (2.51 g, $7.50 \mathrm{mmol}, 1.00$ equiv) in methano $(98.0 \mathrm{~mL})$ at $0^{\circ} \mathrm{C}$. Iodine $(5.71 \mathrm{~g}, 22.5 \mathrm{mmol}, 3.00$ equiv) was added to the reaction mixture which was warmed to $\mathrm{rt}$ and stirred for $1 \mathrm{~h}$. Volatiles were removed under vacuum and $\mathrm{HCl}(1 \mathrm{M}, 30 \mathrm{~mL})$ was added. The reaction mixture was extracted with EtOAc $(3 \times 30 \mathrm{~mL})$. The combined organic layers were washed with $\mathrm{Na}_{2} \mathrm{~S}_{2} \mathrm{O}_{3}$ (sat. aq., $20 \mathrm{~mL}$ ), water $(10 \mathrm{~mL}$ ), brine $(10 \mathrm{~mL})$, dried over $\mathrm{MgSO}_{4}$, filtrated over cotton wool and concentrated under vacuum using a rotary evaporator to give the crude product. This was purified by column chromatography over $\mathrm{SiO}_{2}$, using PET/EtOAc (90:10) to give the title product $\mathbf{1 4}$ as an orange solid $(2.69 \mathrm{~g}$ 97\%).

$\operatorname{Mp} 75-77^{\circ} \mathrm{C}$.

$\nu_{\max }\left(\right.$ film) $/ \mathrm{cm}^{-1} 2942,1706,1465,1375,1344,1273,1191,1139,1030$ $696,865,843,819,773$

${ }^{1} \mathrm{H}$ NMR (400 MHz, $\left.\mathrm{CDCl}_{3}\right): \delta(\mathrm{ppm}) 4.78(\mathrm{t}, J=1.9 \mathrm{~Hz}, 2 \mathrm{H}, \mathrm{H} 2+\mathrm{H} 5), 4.41$ $\left(\mathrm{t}, J=1.7 \mathrm{~Hz}, 2 \mathrm{H}, \mathrm{H} 2^{\prime}+\mathrm{H}^{\prime}\right), 4.38(\mathrm{t}, J=1.9 \mathrm{~Hz}, 2 \mathrm{H}, \mathrm{H} 3+\mathrm{H} 4), 4.17(\mathrm{t}, J=1.7$ $\left.\mathrm{Hz}, 2 \mathrm{H}, \mathrm{H} 3^{\prime}+\mathrm{H}^{\prime}\right), 3.82\left(\mathrm{~s}, 3 \mathrm{H}, \mathrm{CH}_{3}\right)$.

${ }^{13} \mathrm{C}$ NMR (100 MHz, $\left.\mathrm{CDCl}_{3}\right): \delta(\mathrm{ppm}) 171.0(\mathrm{C}=0), 76.2\left(\mathrm{C}^{\prime}+\mathrm{C}^{\prime}\right), 74.4(\mathrm{C} 3$ + C4=, 73.5 (C1), 72.7 (C2 + C5), 70.7 (C3' + C4'), 51.8 (CH3), 40.4 (C1').

Mass: 370 [M].

\section{1'-Iodoferrocenecarboxylic acid (15)}

[CAS Reg. No. 31832-98-1]

$\mathrm{NaOH}$ (1.40 g, 35.0 mmol, 5.00 equiv) in $\mathrm{H}_{2} \mathrm{O}(42.0 \mathrm{~mL})$ was added to a solution of compound 14 ( $2.60 \mathrm{~g}, 7.00 \mathrm{mmol}, 1.00$ equiv) in methanol $(35.0 \mathrm{~mL})$ at $\mathrm{rt}$ and the reaction mixture was heated at $80{ }^{\circ} \mathrm{C}$ in a preheated bath for $75 \mathrm{~min}$. The reaction mixture was cooled to $\mathrm{rt}$ and methanol was removed under vacuum using a rotary evaporator. The resulting solution was cooled to $0{ }^{\circ} \mathrm{C}$ and $\mathrm{HCl}$ (35\% aq.) was added dropwise until pH 1 was reached. The resulting solid was filtrated and washed with cooled $\left(0^{\circ} \mathrm{C}\right)$ water $(2 \times 5 \mathrm{~mL})$ and pentane $(10 \mathrm{~mL})$. Drying the solid under high vacuum with a $\mathrm{P}_{2} \mathrm{O}_{5}$ trap afforded the title product 15 as a dark red solid $(2.39 \mathrm{~g}, 96 \%)$

Mp $153-155^{\circ} \mathrm{C}$

$\nu_{\max }\left(\right.$ film) $/ \mathrm{cm}^{-1}$ 3108, 2857 (br), 2636, 2562, 1667, 1482, 1296, 1166, $1025,840,745$.

${ }^{1} \mathrm{H} \mathrm{NMR}\left(500 \mathrm{MHz}, \mathrm{CDCl}_{3}\right): \delta(\mathrm{ppm}) 4.86(\mathrm{~s}, 2 \mathrm{H}, \mathrm{H} 2+\mathrm{H} 5), 4.48$ (s, 2H, H2' + H5') 4.47 (s, 2H, H3 + H4), 4.28 (s, 2H, H3' + H4'). Acid proton missing. ${ }^{13} \mathrm{C} \mathrm{NMR}\left(125 \mathrm{MHz}, \mathrm{CDCl}_{3}\right): \delta(\mathrm{ppm}) 176.9(\mathrm{C}=0), 76.5\left(\mathrm{C}^{\prime}+\mathrm{C}^{\prime}\right), 75.4(\mathrm{C} 3$ + C4), 73.2 (C2 + C5), $72.1(\mathrm{C} 1), 71.2\left(\mathrm{C}^{\prime}+\mathrm{C}^{\prime}\right), 40.3$ (C1').

\section{1'-Iodoferrocenoyl azide (16)}

Triethylamine ( $4.32 \mathrm{~mL}, 3.14 \mathrm{~g}, 31.0 \mathrm{mmol}, 5.00$ equiv) was added to a solution of compound 15 ( 2.20 g, $6.20 \mathrm{mmol}, 1.00$ equiv) in $\mathrm{CH}_{2} \mathrm{Cl}_{2}(12.0$ $\mathrm{mL})$ at $40{ }^{\circ} \mathrm{C}$. Diphenylphosphoryl azide $(1.47 \mathrm{~mL}, 1.88 \mathrm{~g}, 6.82 \mathrm{mmol}, 1.10$ equiv) was added dropwise to the reaction mixture which was then kept at the same temperature for $10 \mathrm{~min}$. The reaction mixture was cooled to rt and $\mathrm{HCl}(1.0 \mathrm{M}$ aq., $30 \mathrm{~mL})$ was added. The reaction mixture was extracted with $\mathrm{Et}_{2} \mathrm{O}(2 \times 30 \mathrm{~mL})$ and the combined organic layers were dried over $\mathrm{MgSO}_{4}$, filtrated over cotton wool and concentrated under vacuum using a rotary evaporator to give the crude product. This was purified by column chromatography over $\mathrm{SiO}_{2}$, using pentane/Et $2 \mathrm{O}$ (90:10) to give the title product 16 as a red solid (2.02 g, 85\%).

Mp $102-104{ }^{\circ} \mathrm{C}$.

$\nu_{\max }(\mathrm{film}) / \mathrm{cm}^{-1} 2146,1673,1452,1372,1261,1191,1052,989,829,818$. ${ }^{1} \mathrm{H}$ NMR (500 MHz, $\left.\mathrm{CDCl}_{3}\right): \delta(\mathrm{ppm}) 4.81(\mathrm{t}, J=1.9 \mathrm{~Hz}, 2 \mathrm{H}, \mathrm{H} 2+\mathrm{H} 5), 4.49$ $(\mathrm{t}, J=1.9 \mathrm{~Hz}, 2 \mathrm{H}, \mathrm{H} 3+\mathrm{H} 4), 4.47\left(\mathrm{t}, J=1.8 \mathrm{~Hz}, 2 \mathrm{H}, \mathrm{H} 2^{\prime}+\mathrm{H} 5^{\prime}\right), 4.24(\mathrm{t}, J=1.8$ $\left.\mathrm{Hz}, 2 \mathrm{H}, \mathrm{H} 3^{\prime}+\mathrm{H} 4^{\prime}\right)$.

${ }^{13} \mathrm{C} \mathrm{NMR}\left(125 \mathrm{MHz}, \mathrm{CDCl}_{3}\right): \delta(\mathrm{ppm}) 176.0(\mathrm{C}=0), 76.6\left(\mathrm{C}^{\prime}+\mathrm{C}^{\prime}\right), 75.7(\mathrm{C} 3$ + C4), 74.5 (C1), 72.8 (C2 + C5), $71.1\left(\mathrm{C}^{\prime}+\mathrm{C} 4^{\prime}\right), 40.69$ (C1').

\section{1-(tert-Butoxycarbonyl)amino-1'-iodoferrocene (17)}

tert-Butanol ( $2.40 \mathrm{~mL}, 1.85 \mathrm{~g}, 25.0 \mathrm{mmol}, 5.00$ equiv) was added to a solution of compound 16 ( $1.85 \mathrm{~g}, 5.00 \mathrm{mmol}, 1.00$ equiv) in toluene (31.0 $\mathrm{mL}$ ) at $\mathrm{rt}$ and the reaction was heated at $100{ }^{\circ} \mathrm{C}$ for $1 \mathrm{~h}$ in a pre-heated oil bath. The reaction mixture was cooled to $\mathrm{rt}$ and volatiles were removed under vacuum to give the crude product. This was purified by column chromatography, using PET-EtOAc $(90: 10)$ to give the title product $\mathbf{1 7}$ as an orange solid $(1.81 \mathrm{~g}, 85 \%)$.

Mp $100-102{ }^{\circ} \mathrm{C}$.

$v_{\max }($ film $) / \mathrm{cm}^{-1} 3354,2147,1697,1550,1389,1366,1252,1157,1073$, $1028,867,808$.

${ }^{1} \mathrm{H} \mathrm{NMR}\left(500 \mathrm{MHz}, \mathrm{CDCl}_{3}\right): \delta(\mathrm{ppm}) 5.86(\mathrm{br} \mathrm{s}, 1 \mathrm{H}, \mathrm{NH}), 4.42(\mathrm{br} \mathrm{s}, 2 \mathrm{H}, \mathrm{H} 2$ + H5), 4.38 (s, 2H, H2' + H5'), 4.13 (s, 2H, H3' + H4'), 3.98 (s, 2H, H3 + H4), $1.51\left(\mathrm{~s}, 9 \mathrm{H}, \mathrm{C}\left(\mathrm{CH}_{3}\right)_{3}\right)$.

${ }^{13} \mathrm{C} \mathrm{NMR}\left(125 \mathrm{MHz}, \mathrm{CDCl}_{3}\right): \delta(\mathrm{ppm}) 153.3(\mathrm{C}=0), 97.5(\mathrm{C} 1), 80.3\left(\mathrm{C}\left(\mathrm{CH}_{3}\right)_{3}\right)$, $75.6\left(\mathrm{C} 2^{\prime}+\mathrm{C} 5^{\prime}\right), 69.7\left(\mathrm{C}^{\prime}+\mathrm{C}^{\prime}\right), 67.1(\mathrm{C} 3+\mathrm{C} 4), 62.9(\mathrm{C} 2+\mathrm{C} 5), 42.6\left(\mathrm{C}^{\prime}\right)$, $28.5\left(\mathrm{C}\left(\mathrm{CH}_{3}\right)_{3}\right)$.

\section{1'-Iodoferrocenamine hydrochloride (18)}

$\mathrm{HCl}$ in $\mathrm{Et}_{2} \mathrm{O}(\approx 5.00 \mathrm{M}, 24.0 \mathrm{~mL}, 120 \mathrm{mmol}, 40.0$ equiv) was added to a solution of compound 17 (1.28 g, $3.00 \mathrm{mmol}, 1.00$ equiv) in $\mathrm{Et}_{2} \mathrm{O}(30.0 \mathrm{~mL})$ and the reaction mixture was stirred at $\mathrm{rt}$ for $2 \mathrm{~h}$. The resulting solid was quickly filtrated and washed with $\mathrm{Et}_{2} \mathrm{O}(2 \times 10 \mathrm{~mL})$ and pentane $(10 \mathrm{~mL})$ and dried under high vacuum to give the title product 18 as an orange solid (800 mg, 74\%).

Mp $146-148{ }^{\circ} \mathrm{C}$.

$v_{\max }($ film $) / \mathrm{cm}^{-1} 2802,2601,2569,1672,1608,1521,1469,1375,1143$, $1023,855,833,818$.

${ }^{1} \mathrm{H}$ NMR (500 MHz, $\left.\mathrm{CDCl}_{3}\right): \delta(\mathrm{ppm}) 9.84\left(\mathrm{br} \mathrm{s}, 3 \mathrm{H}, \mathrm{NH}_{3}{ }^{+}\right), 4.61\left(\mathrm{~s}, 2 \mathrm{H}, \mathrm{H} 2^{\prime}\right.$ + H5'), 4.43 (s, 2H, H2 + H5), 4.39 (s, 2H, H3' + H4'), 4.13 (s, 2H, H3 + H4). ${ }^{13} \mathrm{C}$ NMR (125 MHz, $\left.\mathrm{CDCl}_{3}\right): \delta(\mathrm{ppm}) 89.2(\mathrm{C} 1), 75.7\left(\mathrm{C}^{\prime}+\mathrm{C}^{\prime}\right), 71.1\left(\mathrm{C}^{\prime}{ }^{\prime}+\right.$ C4'), 70.1 (C3 + C4), 65.7 (C2 + C5), 39.0 (C1'). 


\section{1-(Dimethylamino)-1'-iodoferrocene (19)}

Sodium cyanoborohydride (754 mg, $12.0 \mathrm{mmol}, 6.00$ equiv) was added portionwise to a solution of compound $18(727 \mathrm{mg}, 2.00 \mathrm{mmol}, 1.00$ equiv) and paraformaldehyde (720 mg, $24.0 \mathrm{mmol}, 12.0$ equiv) in glacial acetic acid $(6.00 \mathrm{~mL})$ at $\mathrm{rt}$. The reaction mixture was stirred for $4 \mathrm{~h}$ before paraformaldehyde (120 mg, $4.00 \mathrm{mmol}, 2.00$ equiv) and sodium cyanoborohydride (120 mg, $2.00 \mathrm{mmol}, 1.00$ equiv) were added to the reaction mixture which was stirred at rt overnight. EtOAc $(20 \mathrm{~mL})$ was added, followed by solid $\mathrm{K}_{2} \mathrm{CO}_{3}$ until $\mathrm{pH} 8$ was reached. The layers were separated and the aqueous layer was extracted with EtOAc $(2 \times 10 \mathrm{~mL})$ The combined organic layers were dried over $\mathrm{MgSO}_{4}$, filtrated over cotton wool and concentrated under vacuum using a rotary evaporator to give the crude product. This was purified by column chromatography over $\mathrm{SiO}_{2}$, using PET/EtOAc (80:20 to 70:30) to give the title product 19 as an orange solid (284 $\mathrm{mg}, 40 \%$ ).

Mp 52-54 ${ }^{\circ} \mathrm{C}$.

$\nu_{\max }\left(\right.$ film) $/ \mathrm{cm}^{-1} 3094,2922,1628,1598,1487,1445,1422,1367,1354$, 1333, 1293, 1052, 1028, 1008, 814, 792, 726, 700.

${ }^{1} \mathrm{H}$ NMR (500 MHz, $\left.\mathrm{CDCl}_{3}\right): \delta(\mathrm{ppm}) 4.52$ (s, 2H, H2' + H5'), 4.24 (s, 2H, H3' $+\mathrm{H}^{\prime}$ ) $, 3.97(\mathrm{~s}, 2 \mathrm{H}, \mathrm{H} 3+\mathrm{H} 4), 3.71(\mathrm{~s}, 2 \mathrm{H}, \mathrm{H} 2+\mathrm{H} 5), 2.66\left(\mathrm{br} \mathrm{s}, 6 \mathrm{H}, 2 \times \mathrm{CH}_{3}\right)$

${ }^{13} \mathrm{C}$ NMR (125 MHz, $\left.\mathrm{CDCl}_{3}\right): \delta(\mathrm{ppm}) 117.2(\mathrm{C} 1), 73.1\left(\mathrm{C}^{\prime}+\mathrm{C}^{\prime}\right), 67.8\left(\mathrm{C}^{\prime}\right.$ + $\left.4^{\prime}\right), 66.9(\mathrm{C} 3+\mathrm{C} 4), 58.1(\mathrm{C} 2+\mathrm{C} 5), 42.4\left(2 \times \mathrm{CH}_{3}\right), 40.6\left(\mathrm{C}^{\prime}\right)$.

\section{Acknowledgment}

The authors would like to acknowledge Région Bretagne for a postdoctoral fellowship grant (L. K.). This work was supported by the Université de Rennes 1 and CNRS. We gratefully acknowledge the Fonds Européen de Développement Régional (FEDER; D8 VENTURE Bruker AXS diffractometer) and Thermofisher (generous gift of 2,2,6,6tetramethylpiperidine). This research has been performed as part of the Indo-French 'Joint Laboratory for Natural Products and Synthesis towards Affordable Health'. The authors would like to acknowledge Mehdi Tazi for growing crystals of compound rac-2.

\section{References}

1. (a) Kealy, T. J.; Pauson, P. L. Nature 1951, 168, 1039; (b) Miller, S. A.; Tebboth, J. A.; Tremaine, J. F. J. Chem. Soc. 1952, 632; (c) Ferrocenes: Homogeneous Catalysis, Organic Synthesis, Materials Science, Togni, A.; Hayashi, T., Eds. VCH: Weinheim, 1995.

2. (a) Chiral Ferrocenes in Asymmetric Catalysis, Dai, L.-X.; Hou, X.-L., Eds. Wiley-VCH: Weinheim, 2010; (b) Zhu, J. C.; Cui, D. X.; Li, Y. D.; Jiang, R.; Chen, W. P.; Wang, P. A. ChemCatChem 2018, 10, 907.

3. (a) Ferrocenes: Ligands, Materials and Biomolecules, Štěpnička, P., Ed. Wiley: Chichester, 2008; (b) Scottwell, S. Ø.; Crowley, J. D. Chem. Commun. 2016, 52, 2451; (c) Inkpen, M. S.; Scheerer, S.; Linseis, M.; White, A. J. P.; Winter, R. F.; Albrecht, T.; Long, N. J. Nat. Chem. 2016, 8,825 .

4. (a) Kirin, S. I.; Kraatz, H.-B.; Metzler-Nolte, N. Chem. Soc. Rev. 2006, 35, 348; (b) Singh, A.; Lumb, I.; Mehra, V.; Kumar, V. Dalton Trans. 2019, 48, 2840.

5. Petrov, A. R.; Jess, K.; Freytag, M.; Jones, P. G.; Tamm, M. Organometallics 2013, 32, 5946.

6. Erb, W.; Mongin, F. Synthesis 2019, 51, 146

7. Butenschön, H. Synthesis 2018, 50, 3787.

8. Butler, I. R.; Boyes, A. L.; Kelly, G.; Quayle, S. C.; Herzig, T.; Szewczyk, J. Inorg. Chem. Commun. 1999, 2, 403.

9. Kleoff, M.; Schwan, J.; Boeser, L.; Hartmayer, B.; Christmann, M.; Sarkar, B.; Heretsch, P. Org. Lett. 2020, 22, 902.

10. (a) Roemer, M.; Kang, Y. K.; Chung, Y. K.; Lentz, D. Chem. Eur. J. 2012, 18, 3371; (b) Roemer, M.; Donnadieu, B.; Nijhuis, C. A. Eur. J. Inorg. Chem. 2016, 2016, 1314.

11. Ilyashenko, G.; Al-Safadi, R.; Donnan, R.; Dubrovka, R.; Pancholi, J.; Watkinson, M.; Whiting, A. RSC Advances 2013, 3, 17081.

12. Wright, M. E. Organometallics 1990, 9, 853.

13. Inouye, M.; Hyodo, Y.; Nakazumi, H. J. Org. Chem. 1999, 64, 2704.
14. Lai, L.-L.; Dong, T.-Y.J. Chem. Soc., Chem. Commun. 1994, 2347. 15. Hall, D. W.; Richards, J. H. J. Org. Chem. 1963, 28, 1549.

16. (a) Guo, J.; Zhuang, S.; Chen, S.; Zhang, S.; Yuan, Y. Chinese Journal of Organic Chemistry 2009, 29, 1264; (b) Wu, K.-Q.; Guo, J.; Yan, J.-F.; Xie, L. L.; Xu, F.-B.; Bai, S.; Nockemann, P.; Yuan, Y.-F. Organometallics 2011, 30, 3504.

17. Iftime, G.; Moreau-Bossuet, C.; Manoury, E.; Balavoine, G. G. A. Chem. Commun. 1996, 527.

18. Chong, J. M.; Hegedus, L. S. Organometallics 2004, 23, 1010.

19. Ingham, S. L.; Khan, M. S.; Lewis, J.; Long, N. J.; Raithby, P. R. J. Organomet. Chem. 1994, 470, 153.

20. (a) Dong, T.-Y.; Chang, S.-W.; Lin, S.-F.; Lin, M.-C.; Wen, Y.-S.; Lee, L. Organometallics 2006, 25, 2018; (b) Ma, J.; Vollmann, M.; Menzel, H.; Pohle, S.; Butenschön, H. J. Inorg. Organomet. P. 2008, 18, 41; (c) Wilson, L. E.; Hassenrück, C.; Winter, R. F.; White, A. J. P.; Albrecht, T.; Long, N. J. Eur. J. Inorg. Chem. 2017, 2017, 496.

21. Bakar, M. A.; Sergeeva, N. N.; Juillard, T.; Senge, M. O. Organometallics 2011, 30, 3225.

22. Schaarschmidt, D.; Lang, H. Organometallics 2010, 29, 4196.

23. Szarka, Z.; Kuik, Á.; Skoda-Földes, R.; Kollár, L. J. Organomet. Chem. 2004, 689, 2770.

24. (a) Tazi, M.; Erb, W.; Halauko, Y. S.; Ivashkevich, O. A.; Matulis, V. E.; Roisnel, T.; Dorcet, V.; Mongin, F. Organometallics 2017, 36, 4770; (b) Erb, W.; Hurvois, J.-P.; Roisnel, T.; Dorcet, V. Organometallics 2018, 37, 3780; (c) Tazi, M.; Hedidi, M.; Erb, W.; Halauko, Y. S.; Ivashkevich, O. A.; Matulis, V. E.; Roisnel, T.; Dorcet, V.; BentabedAbabsa, G.; Mongin, F. Organometallics 2018, 37, 2207; (d) Erb, W.; Roisnel, T. Chem. Commun. 2019, 55, 9132; (e) Hedidi, M.; Dayaker, G.; Kitazawa, Y.; Tatsuya, Y.; Kimura, M.; Erb, W.; Bentabed-Ababsa, G.; Chevallier, F.; Uchiyama, M.; Gros, P. C.; Mongin, F. New J. Chem. 2019, 43, 14898; (f) Tazi, M.; Erb, W.; Roisnel, T.; Dorcet, V.; Mongin, F.; Low, P. J. Org. Biomol. Chem 2019, 27, 9352.

25. Tsukazaki, M.; Tinkl, M.; Roglans, A.; Chapell, B. J.; Taylor, N. J.; Snieckus, V. J. Am. Chem. Soc. 1996, 118, 685.

26. Richards, C. J.; Damalidis, T.; Hibbs, D. E.; Hursthouse, M. B. Synlett 1995, 1995, 74 .

27. Erb, W.; Roisnel, T.; Dorcet, V. Synthesis 2019, 51, 3205.

28. Ferber, B.; Top, S.; Welter, R.; Jaouen, G. Chem. Eur. J. 2006, 12, 2081.

29. (a) Togni, A.; Pastor, S. D. J. Org. Chem. 1990, 55, 1649; (b) Fukuzawa, S.-i.; Yamamoto, M.; Kikuchi, S. J. Org. Chem. 2007, 72, 1514.

30. Routaboul, L.; Chiffre, J.; Balavoine, G. G. A.; Daran, J.-C.; Manoury, E. J. Organomet. Chem. 2001, 637-639, 364.

31. (a) Anderson, J. C.; Blake, A. J.; Arnall-Culliford, J. C. Org. Biomol. Chem 2003, 1, 3586; (b) Anderson, J. C.; Osborne, J. Tetrahedron: Asymmetry 2005, 16, 931.

32. Erb, W.; Kadari, L.; Al-Mekhlafi, K.; Roisnel, T.; Dorcet, V.; Radha Krishna, P.; Mongin, F. Adv. Synth. Catal. 2020, 362, 832.

33. Sharpless, K. B.; Akashi, K.; Oshima, K. Tetrahedron Lett. 1976, 17, 2503.

34. Kivrak, A.; Zora, M. J. Organomet. Chem. 2007, 692, 2346.

35. Brunner, A.; Taudien, S.; Riant, O.; Kagan, H. B. Chirality 1997, 9 , 478.

36. Yamada, S.; Morizono, D.; Yamamoto, K. Tetrahedron Lett. 1992, 33, 4329 .

37. Erb, W.; Levanen, G.; Roisnel, T.; Dorcet, V. New J. Chem. 2018, 42, 3808.

38. Metallinos, C.; Zaifman, J.; Dodge, L. Org. Lett. 2008, 10, 3527. 
39. Williams, D. B. G.; Lawton, M. J. Org. Chem. 2010, 75, 8351.

40. Burchat, A. F.; Chong, J. M.; Nielsen, N. J. Organomet. Chem. 1997, 542,281

41. (a) Dong, T.-Y.; Ho, P.-H.; Chang, C.-K. J. Chin. Chem. Soc. 2000, 47, 421; (b) Tisovský, P.; Mečiarová, M.; Šebesta, R. Tetrahedron:
Asymmetry 2011, 22, 536; (c) Pedotti, S.; Patti, A. Tetrahedron 2012, 68,3300 . 